\title{
Pengaruh Waktu Penyimpanan Ekstrak Rennet Abomasum Domba Lokal terhadap Kualitas Keju
}

Trioso Purnawarman ${ }^{(1)}$, Chairun Nisa'(2), Karunia Maghfiroh ${ }^{(3)}$
(1) Bagian Kesmavet, Departemen IImu Penyakit Hewan dan Kesehatan MasyarakatVeteriner, FKH-IPB (trioso18@yahoo.com).

(2) Bagian Anatomi, Histologi dan Embriologi, Departemen Anatomi Fisiologi dan Farmakologi, FKH-IPB (chnisa@yahoo.com).

(3) Mahasiswa Program Sarjana FKH- IPB (karunia_fkh43@yahoo.com).

Diterima 28 Maret 2012/ Disetujui 6 Oktober 2012

\begin{abstract}
The study was aimed to examine the storage effect of rennet extracted from abomasum of local sheep on the texture and organoleptic qualities of cheese including color, flavor, salty taste, and bitter taste. Ten samples of crude rennet extract were divided into two groups which each five samples were stored for 2 weeks and 24 weeks respectively. The rennet extract was then used as milk clotting agent in cheese making process. Streptococcus thermophilus and Lactobacillus bulgaricus were used as starter in those processes. The fresh cheese was coated with beeswax and ripened for 20 days in refrigerator. The ripened cheese was analyzed for the quality. The texture was analyzed by using warner blatzer shear (INSTRON $\left.{ }^{\circledR}\right)$ and the data were evaluated with completely randomized design (CRD). The result showed that both time storage of rennet extract were not significantly influence on cheese texture $(P<0,05)$. The organoleptic tests of color, flavor, salty taste, and bitter taste were rated by 25 panelists and then the data were analyzed with Friedman test. The time storage of rennet extract resulted variation on organoleptic quality of cheese. Descriptive statistical analyses provided information that each panelist has varied preferences on cheese samples. It can be concluded that the storage of rennet extract had no significantly influence on the texture of cheese and provided variation on organoleptic test.
\end{abstract}

Keywords: storage, rennet extract, cheese, organoleptic test.

\section{PENDAHULUAN}

\section{Latar Belakang}

Domba lokal telah diketahui memiliki potensi yang besar sebagai salah satu sumber rennet, yaitu dari hasil ekstraksi mukosa abomasumnya (Nisa et al. 2007). Potensi tersebut belum dimanfaatkan secara maksimal. Abomasum yang merupakan bagian dari lambung kelenjar domba masih dianggap sebatas limbah ikutan hasil pemotongan.

Ekstrak abomasum (rennet) merupakan bahan bioaktif yang umum digunakan sebagai koagulan dalam proses pembuatan keju. Selain dari sapi muda (Andren et al. 1982), rennet juga telah dikembangkan dari hewan ruminansia lain, tanaman (Ogugua et al. 1987), dan mikroba yang direkayasa secara genetik (genetic modified organism = GMO) (Van Dijck 1999). Penelitian yang telah dilakukan sebelumnya memberikan informasi bahwa ekstrak rennet dari abomasum domba lokal umur dewasa muda dapat mengkoagulasikan susu dengan baik (Fitriyani 2006; Nisa et al. 2007).

Keju merupakan salah satu produk olahan susu dengan nilai gizi yang lengkap serta memiliki cita rasa yang khas, sehingga digemari oleh masyarakat. Untuk memenuhi kebutuhan keju yang semakin meningkat perlu dipikirkan alternatif rennet yang diproduksi 
dalam negeri untuk mengurangi ketergantungan terhadap produk rennet impor yang memiliki harga relatif mahal dan belum terjamin kehalalannya oleh konsumen Indonesia yang mayoritas muslim (Anonim 2004).

Industri keju membutuhkan rennet secara kontinyu untuk memenuhi kebutuhan produksi. Oleh karena itu, rennet sebaiknya dapat disimpan dalam waktu yang cukup lama. Menurut Sari (2009), rennet hasil ekstraksi dari abomasum domba usia dewasa muda ( $5-12$ bulan) dan telah disimpan beku (pada suhu $-30 \stackrel{\circ}{\circ}$ ) selama 10 bulan masih memiliki kemampuan mengkoagulasikan susu dengan baik dan tidak berbeda dengan ekstrak rennet segar.

Keju yang baik ditentukan oleh kualitas organoleptiknya yaitu kualitas yang dinilai dengan menggunakan indera seperti tekstur, warna, aroma dan rasa. Hal ini akan berpengaruh terhadap kesukaan masyarakat terhadap keju. Oleh karena itu, penelitian tentang kualitas keju yang dihasilkan dengan menggunakan ekstrak rennet abomasum domba lokal yang telah mengalami penyimpanan perlu dilakukan.

\section{Tujuan}

Penelitian ini bertujuan untuk mengaplikasikan ekstrak rennet abomasum domba lokal dalam pembuatan keju dan mengamati pengaruh waktu penyimpanan ekstrak rennet dari abomasum domba lokal yang disimpan selama 2 minggu dan 24 minggu terhadap kualitas keju yang dihasilkan.

\section{METODOLOGI}

\section{Waktu dan Tempat}

Penelitian ini dilakukan mulai bulan Desember 2009-Agustus 2010 di Laboratorium Kesehatan Masyarakat Veteriner, Departemen IImu Penyakit Hewan dan Kesehatan Masyarakat, serta Laboratorium Riset Anatomi, Departemen Anatomi Fisiologi dan Farmakologi, Fakultas Kedokteran Hewan, Institut Pertanian Bogor.

\section{Bahan Penelitian}

Penelitian ini menggunakan sepuluh ekstrak rennet yang berasal dari domba lokal umur dewasa muda di bawah satu tahun yang merupakan limbah dari Tempat Potong Hewan (TPH) Ciampea, Bogor. Ekstrak rennet diberi dua perlakuan yaitu disimpan beku selama 2 minggu dan 24 minggu masing-masing sebanyak lima sampel dan keju cheddar komersial sebagai kontrol dalam penilaian tekstur keju.

\section{Metode Penelitian}

\section{Pengujian Aktivitas Rennet dalam Mengkoagulasikan Susu}

Uji aktivitas rennet terhadap koagulasi susu dilakukan dengan menggunakan metode Scott (1986). Susu dimasukkan kedalam Erlenmeyer kemudian dipasteurisasi dengan suhu $72{ }^{\circ} \mathrm{C}$ selama 15 detik dan diukur dengan termometer hingga suhu mencapai $35-40{ }^{\circ} \mathrm{C}$. Susu diambil dengan pipet Pasteur sebanyak $9,7 \mathrm{ml}, 9,6 \mathrm{ml}$ dan 9,5 $\mathrm{ml}$ serta dimasukkan ke dalam gelas piala. Susu tersebut ditambahkan ekstrak rennet dengan volume masing-masing $0,3 \mathrm{ml}, 0,4 \mathrm{ml}$ dan $0,5 \mathrm{ml}$ sehingga terbentuk konsentrasi $3 \%, 4 \%$ dan $5 \%$. Campuran tersebut kemudian diaduk beberapa saat sampai homogen dengan batang pengaduk, didiamkan dan diamati waktu mulai menggumpal serta waktu terjadinya penggumpalan sempurna.

\section{Pembuatan Keju}

Proses pembuatan keju ini dilakukan berdasarkan modifikasi dari metode Ismail (1984). Susu sapi yang akan diolah menjadi keju diambil secara aseptis sebanyak $10 \mathrm{ml}$ 
dan ditambahkan phenolpthalien sebanyak 3-5 tetes kemudian dititrasi untuk menentukan derajat Dornic awal. Susu dipasteurisasi secara high temperature short time (HTST) dengan pemanasan hingga mencapai suhu $72{ }^{\circ} \mathrm{C}$ selama 15 detik dan diaduk perlahan dengan batang pengaduk. Susu didinginkan di dalam baskom yang berisi balok es hingga suhunya menjadi $40{ }^{\circ} \mathrm{C}$. Starter dengan konsentrasi $2 \%$ yang terdiri dari Streptococcus thermophilus dan Lactobacillus bulgaricus ditambahkan ke dalam $500 \mathrm{ml}$ susu kemudian dimasukkan kedalam inkubator $42{ }^{\circ} \mathrm{C}$ selama 60 menit dan dihitung derajat Dornic-nya (Ismail 1984).

Konsentrasi ekstrak rennet 4\% digunakan dalam pembuatan keju berdasarkan pengujian aktivitas rennet dalam mengkoagulasikan susu. Tahap selanjutnya ekstrak rennet dengan konsentrasi tersebut ditambahkan ke dalam $500 \mathrm{ml}$ susu yang telah mengandung starter kemudian diinkubasi pada suhu $35^{\circ} \mathrm{C}$ selama $30-60$ menit hingga terbentuk curd. Kemudian curd dipisahkan dari whey dengan cara dipotong-potong menggunakan pisau dan disaring menggunakan kain belacu yang telah steril. Curd yang tertinggal dalam kain belacu dimasukkan ke dalam plastik, ditutup rapat dan disimpan dalam refrigerator selama 15-17 jam untuk memaksimalkan pengeluaran whey. Selanjutnya curd ditimbang dan ditambahkan garam dengan persentase $4 \%$, dicampurkan hingga homogen kemudian dipres selama 24 jam pada suhu ruang. Tahap yang terakhir adalah pembungkusan curd dengan lilin lebah yang telah dicairkan dan pemeraman yang dilakukan pada suhu $12-14{ }^{\circ} \mathrm{C}$ selama 20 hari untuk membuat keju lunak (Ismail 1984).

\section{Penilaian Kualitas Keju}

Penilaian kualitas keju dilakukan terhadap tekstur, warna, aroma, rasa asin, dan rasa pahit. Tekstur keju dinilai dengan analisis tekstur makanan menggunakan warner blatzer shear (INSTRON $\left.{ }^{\circledR}\right)$. Warna, aroma, rasa asin, dan rasa pahit dinilai berdasarkan metode Soekarto (1985) menggunakan salah satu metode pengujian organoleptik yaitu uji hedonik (uji kesukaan) menggunakan panelis agak terlatih sebanyak 25 orang. Cara penyajiannya yaitu sampel dengan kode tertentu disajikan secara acak kepada panelis. Setiap panelis memberikan penilaiannya untuk setiap sampel berdasarkan tingkat kesukaan dengan kriteria lima skala hedonik yaitu 0 (sangat tidak suka), 1 (tidak suka), 2 (agak suka), 3 (suka), 4 (sangat suka) dan 5 (amat sangat suka).

\section{Analisis Data}

Data tekstur keju diolah menggunakan metode rancangan acak lengkap (RAL) berdasarkan metode Mattjik dan Sumertajaya (2000) untuk mengetahui apakah kedua perlakuan pada penyimpanan rennet berbeda nyata. Data kualitas keju yang dinilai menggunakan metode organoleptik (warna, aroma, rasa asin, dan rasa pahit) diolah menggunakan statistika deskriptif untuk menggambarkan persentase kesukaan panelis terhadap masing-masing sampel keju dan uji non parametrik Friedman untuk mengetahui perbedaan pada respon warna, aroma, rasa asin, dan rasa pahit (Daniel 1989).

\section{HASIL DAN PEMBAHASAN}

\section{Pengujian Aktivitas Rennet dalam Mengkoagulasikan Susu}

Uji koagulasi susu dan pembentukan curd oleh rennet yang telah disimpan selama 2 minggu atau rennet disimpan baru (RDB) memiliki waktu yang lebih cepat dibandingkan dengan rennet yang disimpan 24 minggu atau rennet disimpan lama (RDL) pada masingmasing konsentrasi 3\%, 4\% dan 5\% (Tabel 1). Berdasarkan konsentrasi rennet yang ditambahkan memperlihatkan bahwa waktu koagulasi tercepat terjadi pada konsentrasi 
$5 \%$, diikuti $4 \%$ dan terlama pada konsentrasi $3 \%$. Curd yang terbentuk memperlihatkan hasil yang relatif sama pada konsentrasi $4 \%$ dan 5\% yaitu padat dan terlihat kompak, sedangkan pada konsentrasi 3\% memiliki konsistensi yang kurang kompak (Gambar 1). Hal ini menunjukkan bahwa konsentrasi enzim berpengaruh kepada kecepatan terjadinya koagulasi dan curd yang terbentuk.

Tabel 1 Perbandingan waktu koagulasi antara rennet yang disimpan 2 minggu (RDB) dan 24 minggu (RDL)

\begin{tabular}{cccccc}
\hline $\begin{array}{c}\text { Waktu } \\
\begin{array}{c}\text { Penyimpana } \\
\text { n Rennet } \\
\text { (minggu) }\end{array}\end{array}$ & $\begin{array}{c}\text { Kode } \\
\text { Sampel }\end{array}$ & $\begin{array}{c}\text { Konsentras } \\
\text { i Rennet } \\
(\%)\end{array}$ & $\begin{array}{c}\text { Waktu } \\
\text { Koagulasi } \\
\text { Awal } \\
\text { (menit.detik) }\end{array}$ & $\begin{array}{c}\text { Waktu } \\
\text { Koagulasi } \\
\text { Sempurna } \\
\text { (menit.detik) }\end{array}$ & $\begin{array}{c}\text { Waktu } \\
\text { Koagulasi } \\
\text { (menit.deti } \\
\text { k) }\end{array}$ \\
\hline 2 & RDB & 3 & 01.10 & 05.50 & 04.40 \\
& & 4 & 00.51 & 02.00 & 01.09 \\
24 & RDL & 3 & 00.40 & 01.22 & 00.42 \\
& & 4 & 05.21 & 15.00 & 09.39 \\
& & 5 & 02.46 & 04.00 & 01.14 \\
\end{tabular}

Keterangan: $\mathrm{RDB}=$ Rennet disimpan baru; $\mathrm{RDL}=$ Rennet disimpan lama

Menurut Goenardjoadi (1988), faktor-faktor yang dapat mempengaruhi waktu koagulasi adalah $\mathrm{pH}$, suhu, penambahan $\mathrm{Ca}^{2+}$, dan pengenceran enzim. Faktor-faktor lain yang mempengaruhi kesempurnaan koagulasi yaitu jumlah rennet yang ditambahkan, temperatur, pelapisan $\mathrm{k}$-kasein oleh protein terdenaturasi atau asam amino bebas yang terlepas oleh proteolisis dan lipolisis atau interaksi dengan asam-asam amino pada salah satu sisi ikatan fenilalanina 105 dan metionina 106 di dalam k-kasein (Daulay 1991).

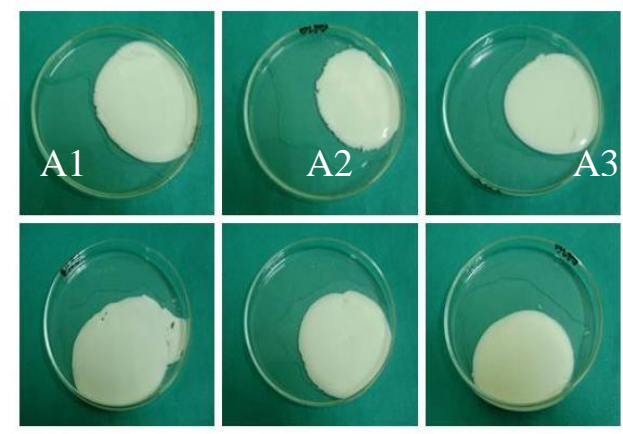

Gambar 1 Hasil koagulasi susu dengan konsentrasi ekstrak rennet masing-masing 3\%, $4 \%$ dan 5\% yang telah disimpan selama 2 minggu (A1, A2, A3) dan 24 minggu (B1, B2, B3).

\section{Pembuatan Keju}

Proses pembua:ian keju menggur iakian konsentras exstrak rennet sebesar $4 \%$. Hal ini didasarkan kepada hasil pengujian awal yang menunjukkan bahwa pada konsentrasi tersebut koagulasi terjadi relatif cepat dan hasil curd yang cukup baik. Menurut Sari (2009), uji koagulasi dengan konsentrasi 3\% dapat membentuk curd yang terpisah dari cairannya (whey). Konsentrasi 3\% tersebut kurang tepat jika diaplikasikan pada pembuatan keju karena konsistensi curd yang dihasilkan kurang kompak. Pembuatan 
keju lunak komersial umumnya menggunakan konsentrasi rennet 0,015\% (Walstra et al. 2006). Konsentrasi rennet tersebut cukup sedikit karena telah mengalami pemurnian, sedangkan rennet yang digunakan dalam penelitian ini masih merupakan ekstrak kasar.

Keju yang dihasilkan dari penambahan rennet yang disimpan selama 2 minggu dan 24 minggu berdasarkan penampilannya relatif sama yaitu memiliki warna agak kekuningan, kadang terlihat sedikit berlubang dan adanya gas pada permukaan keju (Gambar 2).
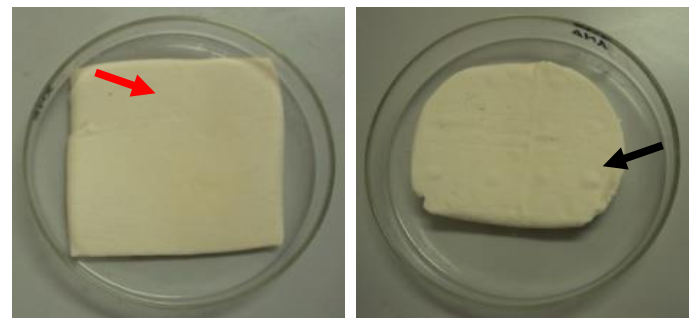

Gambar 2 Penampilan umum keju yang dihasilkan dari penambahan ekstrak rennet RDB (A) terdapat lubang kecil (tanda panah merah), dan RDL (B) terdapat gelembung gas (tanda panah hitam).

\section{Penilaian Kualitas Keju}

Nilai rata-rata uji tekstur keju yang berasal dari RDB yaitu $0,074 \mathrm{~kg} / \mathrm{cm}^{2}$ sedangkan yang berasal dari RDL memiliki rata-rata $0,088 \mathrm{kgf} / \mathrm{cm}^{2}$. Nilai tekstur RDB tersebut mendekati nilai tekstur keju komersial yaitu $0,075 \mathrm{kgf} / \mathrm{cm}^{2}$ sedangkan nilai tekstur RDL cukup berbeda dengan nilai tekstur keju komersial. Berdasarkan uji rancangan acak lengkap pada tekstur keju diperoleh informasi bahwa waktu penyimpanan rennet selama 2 minggu dan 24 minggu tidak berpengaruh terhadap tekstur keju pada taraf nyata $5 \%$. Nilai rata-rata uji tekstur keju terlihat pada Tabel 2.

Tabel 2 Nilai rata-rata uji tekstur keju

\begin{tabular}{cc}
\hline Kode Sampel & Nilai Rata-rata $\left(\mathrm{kgf} / \mathrm{cm}^{2}\right)$ \\
\hline RDB & 0,074 \\
RDL & 0,088 \\
Kontrol & 0,075 \\
\hline
\end{tabular}

Keju mengalami perubahan konsistensi selama pemeraman. Terjadinya perubahan karakteristik tersebut disebabkan oleh hidrolisa protein secara enzimatis yang menyebabkan kasein lebih mudah larut sehingga keju menjadi lunak (Daulay 1991). Menurut Walstra et al. (2006), perubahan tekstur pada keju lunak tidak terlihat nyata. Pada awal pemeraman, keju memiliki $\mathrm{pH}$ yang rendah, terlihat putih dan tidak mengkilap, namun seiring dengan proses pematangan keju akan berubah menjadi halus dan kekuningan. Evaluasi sensoris tekstur, warna, rasa dan penampilan umum memberikan hasil yang baik seiring dengan penambah-an waktu pemeraman (El-Nimr et al. 2010).

Penilaian terhadap kualitas organoleptik keju (warna, aroma, rasa asin, dan rasa pahit) pada taraf nyata 5\% menunjukkan bahwa kombinasi RDB2 dengan RDL3 memberikan pengaruh yang berbeda terhadap warna dan rasa pahit keju. Hasil yang berbeda ditunjukkan oleh kombinasi RDB5 dan RDL5 yaitu pada perlakuan tersebut tidak berbeda nyata pada respon warna, aroma, rasa asin dan rasa pahit. Hal ini menunjukkan bahwa kelima ekstrak rennet pada masing-masing waktu penyimpanan 
memiliki jumlah enzim khimosin dan pepsin yang berbeda-beda sehingga menghasilkan karakteristik keju yang berbeda. Menurut Daulay (1991), rennet yang tertinggal dalam curd memungkinkan bakteri untuk membentuk asam laktat yang dapat merubah curd secara kimiawi menjadi keju.

Persentase kesukaan panelis terhadap kualitas organoleptik keju diperoleh berdasarkan uji statistika deskriptif. Hasil uji tersebut menunjukkan bahwa warna sampel keju yang berasal dari RDB dan RDL didominasi oleh skor agak disukai dengan persentase yang berbeda (Gambar 3). Perbedaan kesukaan panelis terhadap warna keju dapat disebabkan oleh subjektifitas panelis serta perbedaan karakteristik warna pada keju. Perbedaan tersebut dapat disebabkan oleh pengaruh enzimatik yang berasal dari mikroflora selama pemeraman serta ekstrak rennet. Aspek kimia selama pemeraman keju memberikan kontribusi yang nyata pada pembentukan fisika kimia, warna dan kualitas organoleptik (El-Nimr et al. 2010). Keju yang dibungkus dengan lilin lebah memiliki warna cukup kuning yang tidak jauh berbeda dengan warna keju komersial. Selain itu, warna pada makanan umumnya disebabkan oleh warna natural pada bahan makanan tersebut (El-Nimr et al. 2010). Menurut McSweeney (2004) dan Dufosse et al. (2005), warna pada keju dibentuk oleh berbagai faktor di antaranya pigmen susu (beta karoten). Perubahan warna keju dapat dikaitkan dengan aktivitas biokimia mikroflora natif, teknologi proses dan teknik pemeraman. Pemeraman dapat meningkatkan tingkat kekuningan keju (Dufosse et al. 2005; Pinho et al. 2005).

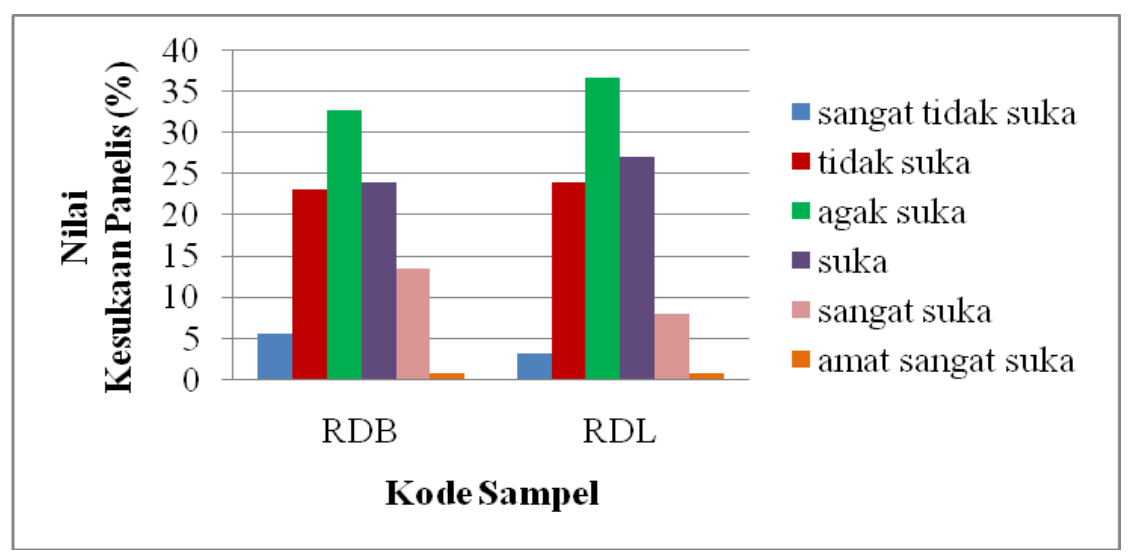

Gambar 3 Persentase nilai kesukaan panelis terhadap karakteristik warna berdasarkan skala hedonik pada keju RDB dan RDL.

Aroma sampel keju yang berasal dari RDB didominasi oleh skor agak disukai sedangkan sampel yang berasal dari RDL didominasi oleh skor yang lebih bervariasi yaitu agak disukai hingga sangat tidak disukai (Gambar 4). Pembentukan aroma dan rasa pada keju merupakan fenomena yang kompleks. Komponen volatile penting dalam aroma keju yaitu asam asam lemak, aldehid, keton, alkohol, amine, ester, hidrogen sulfida, dan sulfida-sulfida (Daulay 1991). 


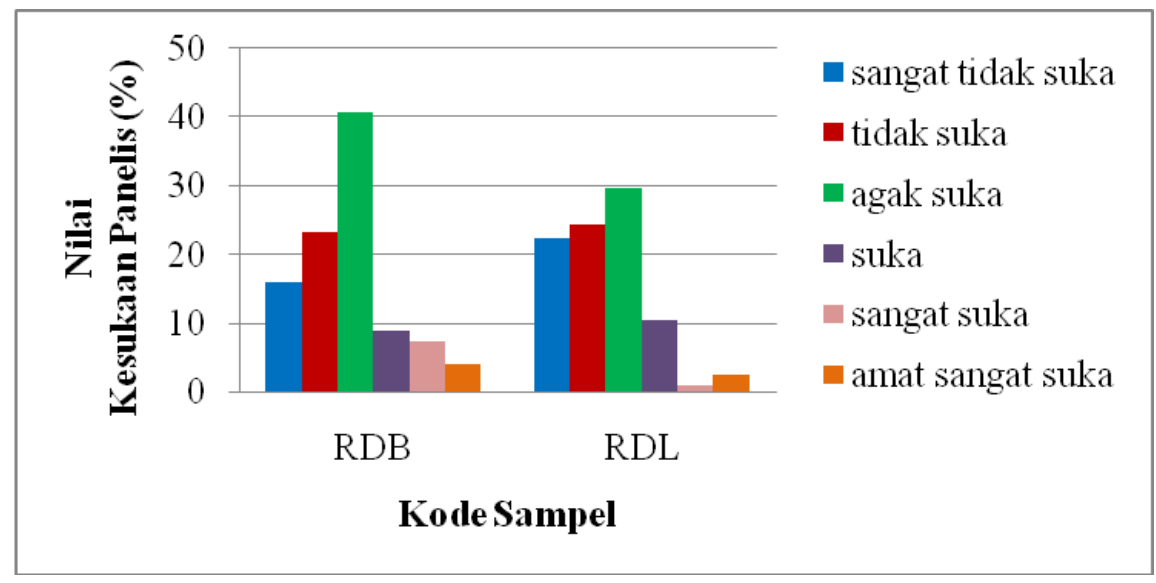

Gambar 4 Persentase nilai kesukaan panelis terhadap karakteristik aroma berdasarkan skala hedonik pada keju RDB dan RDL.

Hasil uji statistika deskriptif rasa asin pada Gambar 5 menunjukkan bahwa sampel keju yang berasal dari RDB didominasi oleh skor agak disukai sedangkan sampel keju yang berasal dari RDL didominasi oleh skor agak disukai dan tidak disukai. Rasa asin pada keju dapat disebabkan oleh proses penggaraman. Garam merupakan salah satu faktor yang penting dalam pembentukan rasa pada keju peram sedangkan starter bakteri berperan penting pada keju fresh (Wasltra et al. 2006). Menurut Marth (1982) penambahan garam berfungsi untuk mempengaruhi cita rasa, tekstur, penampilan umum, kontrol produksi asam laktat, menahan pertumbuhan bakteri pembusuk dan mengurangi kadar air. Hal ini didukung oleh pernyataan Walstra et al. (2006) bahwa fungsi garam yaitu sebagai pengawet, mempengaruhi cita rasa, konsistensi dan berpengaruh selama proses pemeramam.

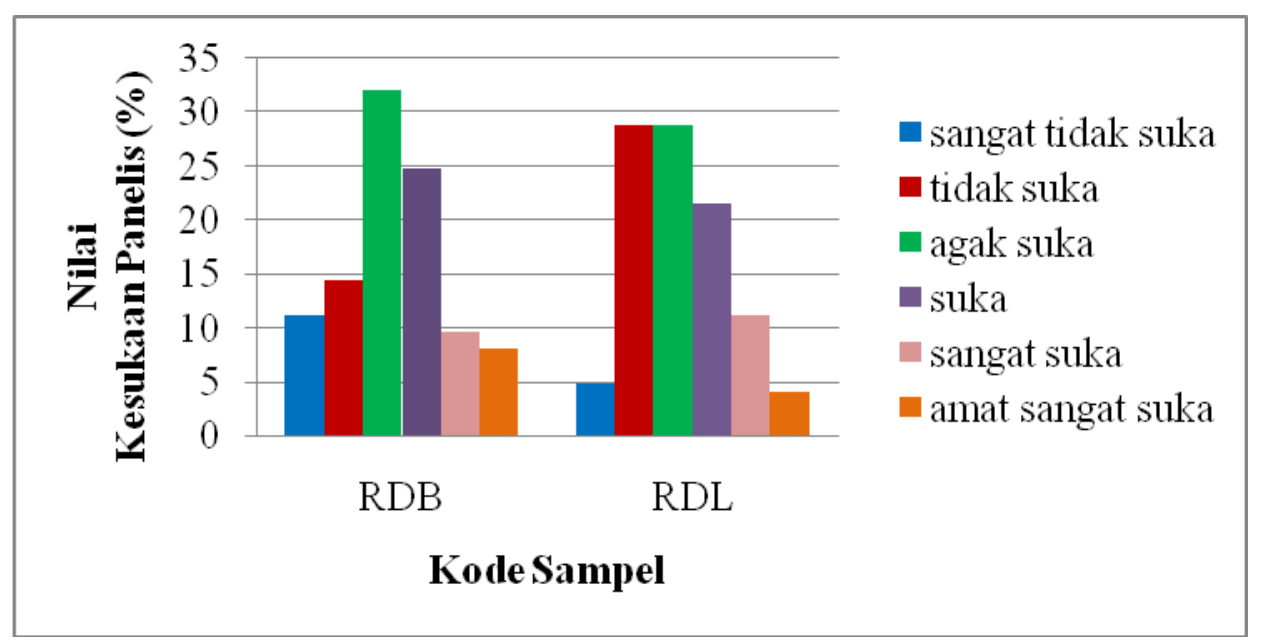

Gambar 5 Persentase nilai kesukaan panelis terhadap karakteristik rasa asin berdasarkan skala hedonik pada keju RDB dan RDL.

Rasa pahit sampel keju yang berasal RDB didominasi oleh skor yang bervariasi yaitu amat sangat disukai, disukai dan tidak disukai sedangkan sampel keju RDL didominasi oleh skor disukai (Gambar 6). Menurut Daulay (1991), beberapa asam amino yang mempunyai rasa pahit adalah metionin, histidin, lisin, triptofan, leusin, isoleusin, arginin dan fenilalanin. Rasa pahit muncul pada keju yang tahap pemeramanya belum 
selesai (keju setengah matang) dan akan hilang pada akhir pemeraman. Rasa pahit terbentuk jika protein didegradasi sehingga menghasilkan beberapa rantai pendek peptida hidrophobik (Walstra et al. 2006).

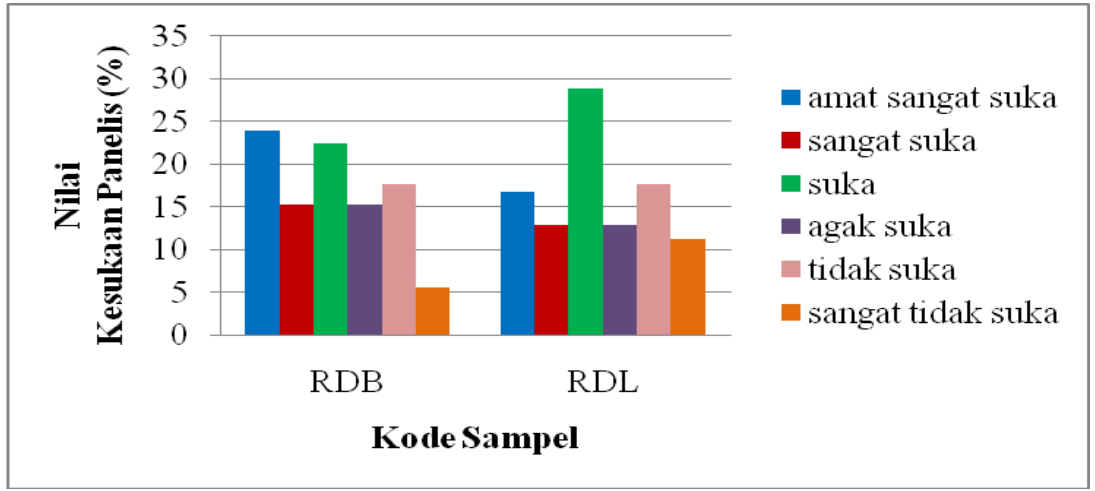

Gambar 6 Persentase nilai kesukaan panelis terhadap karakteristik rasa pahit berdasarkan skala hedonik pada keju RDB dan RDL.

\section{Simpulan}

\section{SIMPULAN DAN SARAN}

Keju yang dihasilkan dari penambahan ekstrak rennet abomasum domba lokal, pada umumnya memiliki warna agak kekuningan, kadang terlihat sedikit berlubang dan adanya gas pada permukaan keju. Selain itu, waktu penyimpanan ekstrak rennet selama 2 minggu dan 24 minggu tidak memberikan perbedaan yang nyata pada tekstur keju namun memberikan pengaruh yang bervariasi pada warna, aroma, rasa asin, dan rasa pahit serta pada kesukaan panelis dari masing-masing keju yang dihasilkan.

\section{Saran}

Perlu dilakukan penelitian lebih lebih lanjut tentang pembuatan keju dengan menggunakan enzim penyusun rennet yang telah dipurifikasi serta pembuatan sediaan rennet dalam bentuk serbuk atau tablet sehingga memudahkan dalam penyimpanan dan pemakaian.

\section{DAFTAR PUSTAKA}

Andren A, Bjork L, Claesson O. 1982. Immunohistochemical studies on the development of prokhimosin and pepsinogen containing cells in bovine abomasal mucosa. $J$ Physiol 327:247-254.

Anonim. 2004. Menelisik Kehalalan Keju. http://www.republika.co.id/berita/18028/menelisik-kehalalan-keju [15 Agustus 2010].

Daniel WW. 1989. Statistika Nonparametrik Terapan. Jakarta: PT Gramedia

Daulay D. 1991. Fermentasi Keju. Bogor: Departemen Pendidikan dan Kebudayaan Direktorat Jendral Pendidikan Tinggi-PAU Pangan dan Gizi IPB.

Dufosse L, Galaup P, Carlet P, Flamin C, Valla A. 2005. Spectrocolorimetry in the CIE $\mathrm{L}^{*} \mathrm{a}^{*} \mathrm{~b}^{*}$ color space as usefultool for monitoring the ripening process and quality of PDO red-smear soft cheese. Food Res Int 38:919-924.

EL-Nimr AA, Hesham A, Eissa M, El-Abd M, Hayam AA Mehriz, Abbas M, Bayoumi HM. 2010. Water activity, color characteristics and sensory properties of egyptian gouda cheese during ripening. J Am Sci 6(10):447-453.

Fitriyani EN. 2006. Studi Morfologi Abomasum Domba Lokal Umur Dewasa Muda (6-12 bulan) dan Uji Aktivitas Ekstrak Mukosanya dalam Mengkoagulasikan Susu [skripsi]. Bogor: Fakultas Kedokteran Hewan, Institut Pertanian Bogor. 
Goenardjoadi. 1988. Evaluasi Karakteristik Ekstrak Rennet dari Abomasum Anak Sapi Perah [skripsi]. Bogor: Fakultas Teknologi Pertanian, Institut Pertanian Bogor.

Ismail N. 1984. Ekstraksi Sederhana Koagulan Susu dari Abomasum Beberapa Spesies Ruminansia untuk Proses Pembuatan Keju [Skripsi]. Bogor: Fakultas Teknologi Pertanian, Institut Pertanian Bogor.

McSweeney PLH. 2004. Biochemistry of cheese ripening. J Technol57(2/3):127-144.

Nisa' C, Agungpriyono S, Maheswari RRA. 2007. Uji aktivitas ekstrak mukosa abomasum domba lokal dalam mengkoagulasikan susu. J Med Vet Ind II (2):58-63.

Ogugua, Aworh C, Muller HG. 1987. Cheese making properties of vegetable rennet from sodom apple (Calotropis procera). Food Chem 26(1):71-79.

Pinho O, Mendes E, Alves MM, Ferreira IM, 2005. Chemical, physical, and sensorial characteristics of terrincho ewe cheese: changes during ripening and intravarietal comparison. J Dairy Sci 87:249-257.

Walstra P, Wouters JT, Geurts TJ. 2006. Dairy Science and Technology. Ed ke-2. New York: CRC Pr. 